\title{
沸騰濃硫酸腐食によるぜい性材料の耐食性評価†
}

$$
\begin{aligned}
& \text { 西山直 紀* 二川正 敏** 井岡:郁 夫** 小貫 } \\
& \text { 清 水三 郎 } * * \text { 衛 藤 基 邦*** 奥 達 雄 }{ }^{* * * *} \text { 倉 部 誠***** }
\end{aligned}
$$

\section{Corrosion Resistance Evaluation of Brittle Materials in Boiling Sulfuric Acid}

by

\author{
Naoki Nishiyama $^{*}$, Masatoshi Futakawa ${ }^{* *}$, Ikuo IokA $^{* *}$, Kaoru OnukI ${ }^{* * *}$ \\ Saburo Shimizu $^{* * *}$, Motokuni Eтo ${ }^{* * *}$, Tatuo OKu ${ }^{* * * *}$ and Makoto KuraBE ${ }^{* * * * *}$
}

The corrosion behaviors of ceramics ( $\mathrm{Si}-\mathrm{SiC}, \mathrm{SiC}, \mathrm{Si}_{3} \mathrm{~N}_{4}, \mathrm{Al}_{2} \mathrm{O}_{3}, \mathrm{ZrO}_{2}$ ) were examined in boiliing $95 \mathrm{wt} \%$ sulfuric acid by measuring weight change, concentration of dissolved ions in the sulfuric acid, 4-point bending strength and apparent hardness calculated from Load-Depth curve obtained by Micro- Indentation technique. The corroded surface and the fracture surface of the specimens were analyzed by SEM and EPMA. The corrosion behaviors of these ceramics were divided into 3 types ; (1) $\mathrm{Si}-\mathrm{SiC}$ and $\mathrm{SiC}$ showed excellent corrosion resistance because of protective oxide films which developed during immersion, (2)the bending strength, apparent hardness of $\mathrm{Si}_{3} \mathrm{~N}_{4}$ and $\mathrm{Al}_{2} \mathrm{O}_{3}$ decreased with increasing immersion time because of corroded layers produced during immersion, and (3) the bending strength of $\mathrm{ZrO}_{2}$ decreased with remarkable weight loss. The thickness (T) of oxide films and corroded layer produced on $\mathrm{Si}-\mathrm{SiC}, \mathrm{SiC}, \mathrm{Si}_{3} \mathrm{~N}_{4}$ and $\mathrm{Al}_{2} \mathrm{O}_{3}$ was evaluated from the depth(d) which was determined by the slope change on Depth-Load/Depth curve. The relationship between T and d was described as T $\approx 10 \mathrm{~d}$. The bending strengths of $\mathrm{Si}_{3} \mathrm{~N}_{4}$ and $\mathrm{Al}_{2} \mathrm{O}_{3}$ were evaluated from thickness $(\mathrm{T})$ of corroded layer and $\mathrm{K}_{\mathrm{Ic}}$ obtained before immersion. As a result, the bending strengths of $\mathrm{Si}_{3} \mathrm{~N}_{4}$ and $\mathrm{Al}_{2} \mathrm{O}_{3}$ could be determined with both the $\mathrm{K}_{\mathrm{Ic}}$ and the equivalent crack length $\left(\mathrm{a}_{\mathrm{e}}\right)$ to $20 \mathrm{~d}$.

Key words : Corrosion, $\mathrm{Si}-\mathrm{SiC}, \mathrm{SiC}, \mathrm{Si}_{3} \mathrm{~N}_{4}, \mathrm{Al}_{2} \mathrm{O}_{3}, \mathrm{ZrO}_{2}$, Sulfuric acid, Apparent hardness, Parameter B, Micro-Indentation, Protective oxide film, Corroded layer, Equivalent crack length

\section{1 緒}

日本原子力研究所では, 高温ガス炉の熱利用系として, 核熱のみを用いて水を分解しクリーンなエネルギー媒体 である水素を製造する熱化学水素製造法 IS (IodineSulfur) プロセスの研究を進めている.․․ 本プロセスは腐 食性の強いハロゲンおよび硫酸を扱うため, 装置材料に ついて十分な検討が必要である。現在までに主要工程装 置材料の候補材料を選定するため, 市販の金属，セラミ ックス，有機材料についてスクリーニング試験を実施し ている. ${ }^{2)}$ 〜) その結果, 本プロセス中で最も厳しいと考 えられる硫酸濃縮・蒸発工程での腐食環境，すなわち沸 騰濃硫酸下では高ケイ素鋳鉄及びセラミックス系材料が, 腐食減量の観点からは耐食性に優れることが分かってい る.これまで, セラミックスの耐食性について，高温高 圧水中 ${ }^{5)}$ 7) , 比較的低濃度の酸性・アルカリ性溶液 中 $^{8) \sim 9)}$ において報告されており, Smialek ら ${ }^{10)}$ p，岡 田ら ${ }^{11)}$ ～13) 荒井ら ${ }^{14)}$ は, 腐食による曲げ強度の劣化を ピット深さまたは腐食層の厚さと関連付けて評価してい る。しかしながら, セラミックス材料の沸騰濃硫酸に対 する耐食性について, 構造材料特性として不可欠な力学
的特性評価という観点から調べられていない.

そこで，5種類のセラミックス材料に対して沸騰硫酸 腐食後曲げ強度試験および破面観察を行い，各材料の腐 食後強度評価を行うと共に，非破壊的強度劣化診断技術 として微小押込み試験法を適用し，その有効性について も検討した。

\section{2 実 験 方 法}

\section{$2 \cdot 1$ 供試材}

本研究に用いた供試材は，ケイ素含浸型炭化ケイ素 $(\mathrm{Si}-\mathrm{SiC})$, 炭化ケイ素 $(\mathrm{SiC})$, 窒化ケイ素 $\left(\mathrm{Si}_{3} \mathrm{~N}_{4}\right)$, アル ミナ $\left(\mathrm{Al}_{2} \mathrm{O}_{3}\right)$ ，イットリア部分安定化ジルコニア Y-PSZ $\left(\mathrm{ZrO}_{2}\right)$ の 5 種類である. $\mathrm{Si}-\mathrm{SiC}$ は $\alpha \mathrm{SiC} と \mathrm{C}$ からなる 成型体に高温で溶融 $\mathrm{Si}$ を残留気孔に含浸充填した反応焼 結材である， $\mathrm{SiC}$ は B (1wt\%)，C (2wt\%) を助剛として 用いた常圧焼結材である. $\mathrm{Si}_{3} \mathrm{~N}_{4}$ は焼結助剤として $\mathrm{SrO}$ $(1 \mathrm{wt} \%) \cdot \mathrm{MgO}(4 \mathrm{wt} \%) \cdot \mathrm{CeO}_{2}(5 \mathrm{wt} \%)$ を用いた常圧焼結 材である. $\mathrm{Al}_{2} \mathrm{O}_{3}$ は純度約 $93 \%$ の常圧焼結材である。試 験片形状はJIS R 1601 曲げ試験法に準拠し, $3 \times 4 \times 40$ $\mathrm{mm}$ とした。

\footnotetext{
$\dagger \quad$ 原稿受理 平成 10 年 7 月 2 日 $\quad$ Received July 2,1998

* 茨城大学大学院 (現在 石川島播磿重工業(株)） テ316-8511 日立市中成沢町, Graduate Student, Ibaraki Univ., Nakanarusawa, Hitach, $316-8511$

** 正 会員 日本原子力研究所 ₹319-1195 茨城県那珂郡東海村, Japan Atomic Energy Res. Inst., Tokai-Mura, Ibaraki, 319-1195

*** 日本原子力研究所 个319-1195 茨城県那珂郡東海村, Japan Atomic Energy Res. Inst. Tokai-Mura, Ibaraki, 319-1195

$* * * *$ 正 会 員 茨城大学工学部機械工学科 ₹ 316-8511 日立市中成沢町, Dept. of Mech. Eng., Ibaraki Univ., Nakanarusawa, Hitachi, 316-8511

***** 三豊オランダ, Landjuweel35, 3905 PE Veenendaal, The Netherlands
} 


\section{$2 \cdot 2$ 浸漬試験}

浸漬試験は，硫酸の蒸発損失を防止するための環流用 コンデンサーを備えた容量 $1000 \mathrm{ml}$ の石英製丸底フラス コに約 $95 \mathrm{wt} \%$ の硫酸約 $750 \mathrm{ml}$ を仕込み, 試験片 4 ヶを石 英製試料ホルダーに同時に保持して液中に浸漬した。 マ ントルヒータにより硫酸を沸騰させ（大気圧中沸点 $320^{\circ} \mathrm{C}$ ）所定時間保った後，加熱を停止した。この沸騰 状態保持時間を浸漬時間とし，最大浸漬時間は 1000 時 間である。浸漬試験後，試験片はエタノール中において 超音波洗浄し，質量変化，寸法変化を測定した。 また， 浸漬後の硫酸中に溶出した元素を定量分析した。

\section{$2 \cdot 3$ 力学的特性評価試験}

浸漬後の試験片すべてについて曲げ強度を測定した。 曲げ試験は，JIS R 1601 に準拠した 4 点曲げ方式で，ク ロスヘッド速度を $0.5 \mathrm{~mm} / \mathrm{min}$ として室温大気中で行っ た。強度は腐食前の断面寸法により評価し，ワイブル分 布（各試験片数：約 10）で整理した。 その後，いくつか の試験片に打いては曲げ試験後の表面打よび破面を SEM，EPMAにより分析した。また, $\mathrm{Si}-\mathrm{SiC}, \mathrm{SiC}, \mathrm{Si}_{3} \mathrm{~N}_{4}$, $\mathrm{Al}_{2} \mathrm{O}_{3}$ については，非破壊的に腐食表面の力学的特性変 化を評価する手段としてビッカース圧子を用いた微小押 込々試験を実施した（試験片数：4本，各試験片に対し て 15 点で計測)。すなわち，押込々深さと押込々荷重の 関係（D-L曲線）を測定し，最大押込み深さと荷重か ら求まる見かけの硬度 $(\mathrm{H})$ ，および D-L曲線の押込み荷 重を押込み哚さで除して求めた D-L/D 曲線の負荷過程 における傾き (以後, B パラメータ ${ }^{14)}$ と呼ぶ) から, 腐 食後の特性評価を試みた。ささらに, 破壊じん性值 $\left(\mathrm{K}_{\mathrm{IC}}\right)$ を,

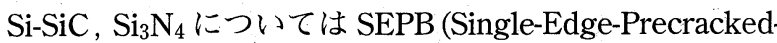
Beam) 法により, さらに $\mathrm{SiC}, \mathrm{Si}_{3} \mathrm{~N}_{4}, \mathrm{Al}_{2} \mathrm{O}_{3}$ についてはビ ッカース圧子を用いてき裂を導入し，熱处理（Ar ガス中 $800^{\circ} \mathrm{C} ， 2$ 時間）を行い残留応力を除去した後， CSF (Controled Surface Flow) 法により評価した（各試験片 数: 約 10).

\section{3 実 験 結 果}

\section{$3 \cdot 1$ 質量変化}

各種セラミックスの浸漬時間と質量変化の関係を Fig 1 に示す，質量変化は，浸漬後の平均質量 $(\mathrm{M})$ を, Table I に示した浸漬前の質量 $\left(\mathrm{M}_{0}\right)$ で規格化し表した. 5 種 類のうち最も著しい質量減を示したのは $\mathrm{ZrO}_{2}$ であり，試 験後の溶液中に主成分 $\mathrm{Zr}$ と焼結助剤 $\mathrm{Y}$ が溶出し, 試験 片寸法が著しく減少した。 $\mathrm{Si}_{3} \mathrm{~N}_{4}, \mathrm{Al}_{2} \mathrm{O}_{3}$ はわずかな質量 減を示した. $\mathrm{Si}_{3} \mathrm{~N}_{4}$ においては浸漬時間とともに焼結助 凰 $\mathrm{Ce}, \mathrm{Mg}, \mathrm{Sr}$ が溶出していた。また $\mathrm{Al}_{2} \mathrm{O}_{3}$ においては 浸漬時間と共に不純物が溶出し，さらに浸漬 1000 時間 後には主成分 $\mathrm{Al}$ が溶出していた、 $\mathrm{Si}-\mathrm{SiC}, \mathrm{SiC}$ はわずか な質量増を示したが, $\mathrm{SiC}$ は試験後の溶液中に焼結助剈 Bの溶出が認められた。

\section{$3 \cdot 2$ 見かけの硬度変化}

浸漬時間に詨する硬度変化 $\mathrm{H} / \mathrm{H}_{0}$ を Fig. 2 に示す。こ こで, $\mathrm{H}_{0}$ は浸漬前の見かけの平均硬度であり, 各種セラ ミックスの平均值を Table I に示す. $\mathrm{Si}-\mathrm{SiC}, \mathrm{SiC} の$
Table I. Properties of Ceramics before immersion.

\begin{tabular}{|c|c|c|c|}
\hline & $\mathrm{M}_{0}(\mathrm{~g})$ & $\sigma_{0}(\mathrm{MPa})$ & $\mathrm{H}_{0}(\mathrm{GPa})$ \\
\hline $\mathrm{Si}-\mathrm{SiC}$ & 1.4 & 280.0 & 13 \\
\hline $\mathrm{SiC}$ & 1.5 & 476.7 & 14 \\
\hline $\mathrm{Si}_{3} \mathrm{~N}_{4}$ & 1.6 & 1194 & 11 \\
\hline $\mathrm{Al}_{2} \mathrm{O}_{3}$ & 1.9 & 333.5 & 17 \\
\hline $\mathrm{ZrO}_{2}$ & 2.9 & 1097 & - \\
\hline
\end{tabular}

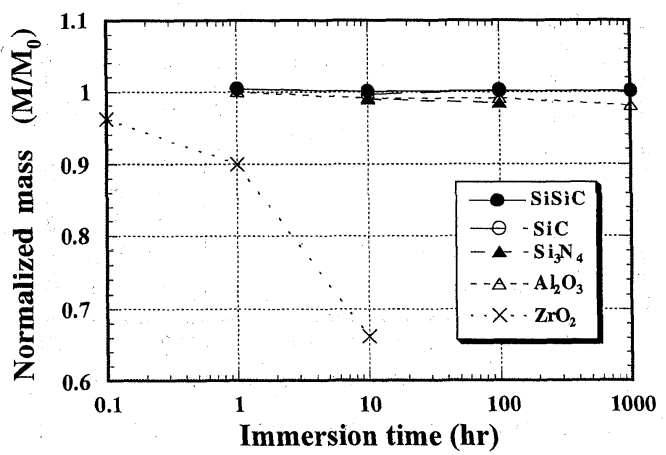

Fig. 1. Normalized mass as a function of immersion time.

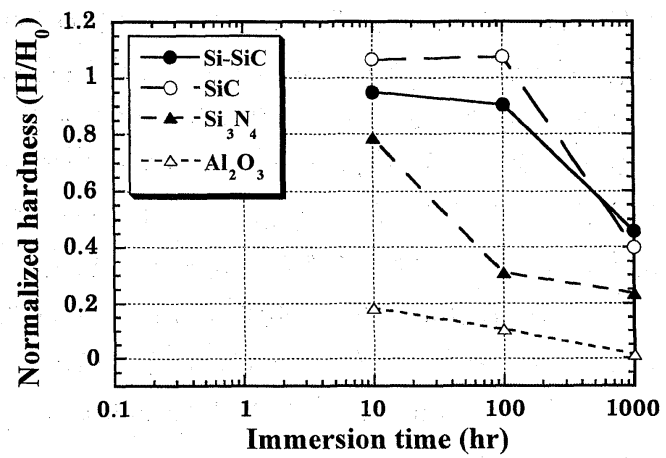

Fig. 2. Normalized apparent hardness as a function of immersion time.

$\mathrm{H} / \mathrm{H}_{0}$ は浸漬 1000 時間後に著しく低下した。一方， $\mathrm{Si}_{3} \mathrm{~N}_{4}$ 打よび $\mathrm{Al}_{2} \mathrm{O}_{3}$ の $\mathrm{H} / \mathrm{H}_{0}$ は浸漬 100 時間後打よび浸漬 10 時間後に著しく低下し，その後緩やかに減少した。 な お，押込み荷重は $98 \mathrm{mN} ， 980 \mathrm{mN}$ である.

\section{$3 \cdot 3$ 強度変化}

各種セラミックスの浸漬時間と曲げ強度の関係を Fig. 3 に示す. 曲げ強度はワイブル分布の平均値 $\sigma$ を用い, Table I に示す浸漬前の曲げ強度 $\left(\sigma_{0}\right)$ で規格化した。 $\mathrm{ZrO}_{2}$ の $\sigma / \sigma_{0}$ は浸漬 0.1 時間後に著しく低下し，その後 は緩やかに減少した. $\mathrm{Si}_{3} \mathrm{~N}_{4}$ の $\sigma / \sigma_{0}$ は浸漬 100 時間後に, $\mathrm{Al}_{2} \mathrm{O}_{3}$ の $\sigma / \sigma_{0}$ は浸漬 1000 時間後に低下した. Si-SiC の $\sigma / \sigma_{0}$ は浸漬 1000 時間後もほとんど変化せず，また $\mathrm{SiC}$ の $\sigma / \sigma_{0}$ は浸漬 100 時間後に増加した。 これらの傾向に ついては 4 章で考察する.

なお， $\mathrm{Si}-\mathrm{SiC}, \mathrm{SiC}, \mathrm{Si}_{3} \mathrm{~N}_{4}, \mathrm{Al}_{2} \mathrm{O}_{3}$ の 4 種類について求め た浸漬前の破壞じん性值を Table II に示す. $\mathrm{Si}_{3} \mathrm{~N}_{4}$ につ いて 2 種類の試験法，すなわち SEMB 法，CSF 法によ って測定した結果，両者はほぼ等しい值を示して抢り， 試験法による相違はほとんどないといえる。 
Table II . Fracture toughness of ceramics.

\begin{tabular}{|l|c|c|c|c|}
\hline & $\mathrm{Si}-\mathrm{SiC}$ & $\mathrm{SiC}$ & $\mathrm{Si}_{3} \mathrm{~N}_{4}$ & $\mathrm{Al}_{2} \mathrm{O}_{3}$ \\
\hline $\mathrm{K}_{\mathrm{Ic}}{ }^{*)}$ & 3.7 & - & 6.3 & - \\
\hline $\mathrm{K}_{\mathrm{Ic}}{ }^{* *)}$ & - & 2.6 & 6.2 & 3.8 \\
\hline \multicolumn{4}{|c}{ SEMB 法、 ${ }^{* *} \mathrm{CSF}$ 法 }
\end{tabular}

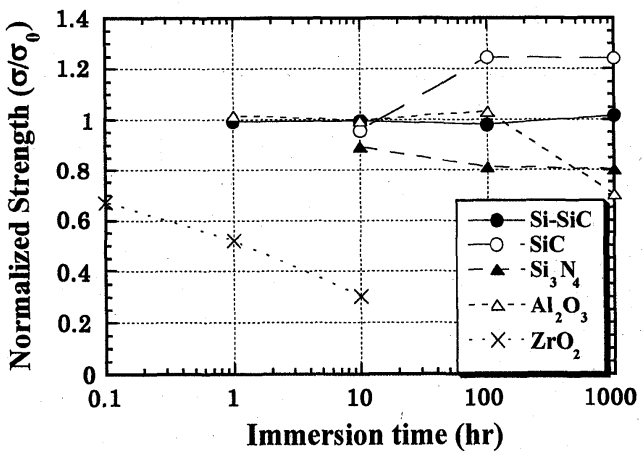

Fig. 3. Normalized bending strength as a function of immersion time.

\section{3・4 D-L/D 曲線}

$\mathrm{Si}-\mathrm{SiC}, \mathrm{SiC}, \mathrm{Si}_{3} \mathrm{~N}_{4}$ 打よび $\mathrm{Al}_{2} \mathrm{O}_{3}$ の代表的な $\mathrm{D}-\mathrm{L} / \mathrm{D}$ 曲 線を Fig. 4 に示す. $\mathrm{Si}-\mathrm{SiC}, \mathrm{SiC}$ の場合（最大押込み荷 重： $98 \mathrm{mN}$ ), 浸漬 100 時間, 1000 時間後の負荷過程に おける曲線の傾き，すなわち $\mathrm{B}$ パラメータがほぼ 2 段階 に変化することが認められる（以後，このB B゚ラメータ が変化する時の押込み深さを $\mathrm{d}$ と定義する)，Si-SiC にお ける $\mathrm{d}$ 值は, 浸漬 100 時間後で約 $0.15 \mu \mathrm{m}, 1000$ 時間後

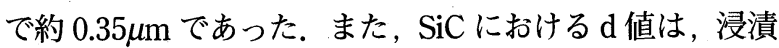
100 時間後で約 $0.12 \mu \mathrm{m}$, 浸漬 1000 時間後で約 $0.21 \mu \mathrm{m}$ であった。

$\mathrm{Si}_{3} \mathrm{~N}_{4}$ の場合（最大押込み荷重：980mN）では，特に 浸漬 1000 時間後の B パラメータが 3 段階に変化し, 各 点での d 值は約 $1.3 \mu \mathrm{m}$ および約 $2.6 \mu \mathrm{m}$ であった。さら に，最大押込み荷重を $98 \mathrm{mN}$ として測定した浸漬 100 時 間後の D-L/D 曲線においても 3 段階に変化することを確 認した.そのときの d 值は, 約 $0.25 \mu \mathrm{m}$ と約 $0.7 \mu \mathrm{m}$ であ った.

$\mathrm{Al}_{2} \mathrm{O}_{3}$ の場合（最大押込み荷重：980mN）では, 浸漬 1000 時間および 100 時間後の B パラメータは 2 段階に 変化しており, d 值は浸漬 100 時間後で約 $2.1 \mu \mathrm{m}$, 浸漬 1000 時間後で約 $5.3 \mu \mathrm{m}$ であった。 また, 押込み荷重 $98 \mathrm{mN}$ で行った試験から得られた浸漬 10 時間および 100 時間後の $\mathrm{B}$ パラメータも 2 段階に変化しており, 各 $\mathrm{d}$ 值 は浸漬 10 時間後で約 $0.6 \mu \mathrm{m}$, 浸漬 100 時間後では約 $2.0 \mu \mathrm{m}$ であった。

\section{$3 \cdot 5$ SEM および EPMA 分析}

Fig. 5 に Si-SiC の浸漬 1000 時間後の破面を示す. 表 面に皮膜の生成が確認できる。皮膜は浸漬 100 時間後の 表面においても確認され, その厚さは浸漬 100 時間後で 約 $1.4 \mu \mathrm{m}$ ，浸漬 1000 時間後で約 $2.6 \mu \mathrm{m}$ であった。 EPMA 分析により Si および O が検出されたことから， シリカ皮膜が形成されたと考えられる.
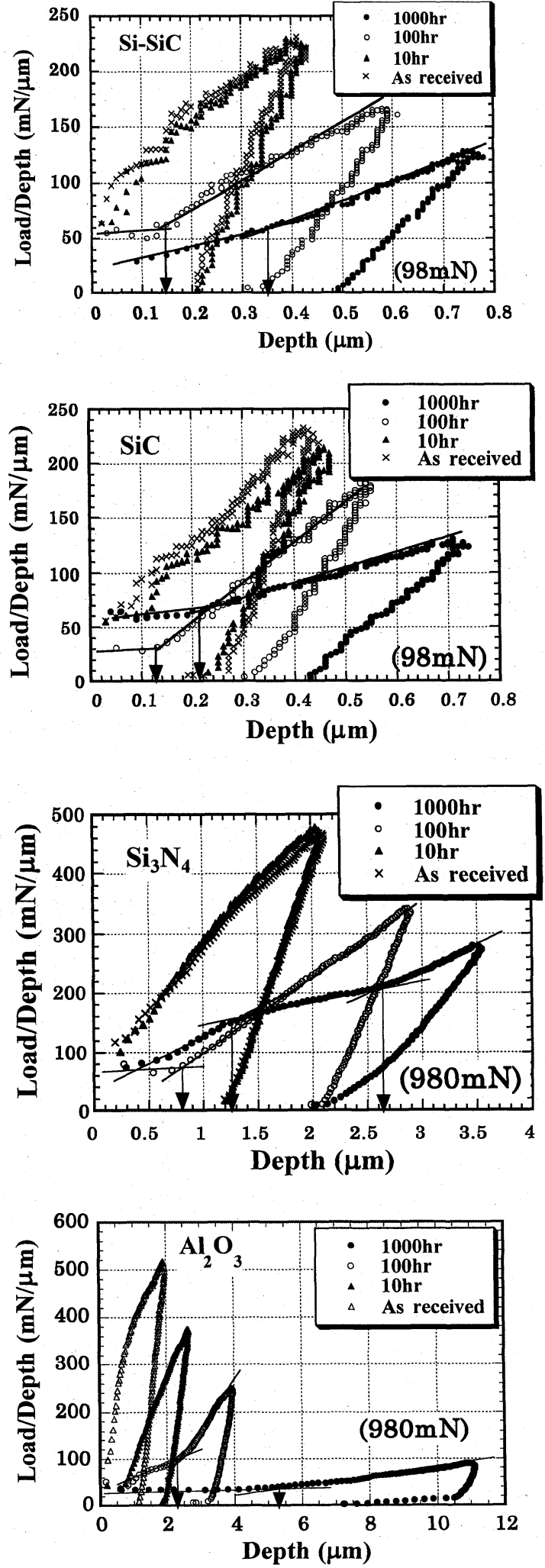

Fig. 4. Depth-Load/Depth curve.

Fig. 6 に $\mathrm{SiC}$ の浸漬 1000 時間後の破面を示す. Si$\mathrm{SiC}$ 同様，表面にシリカ皮膜が生成し，その厚さは浸漬 100 時間後で約 $1.0 \mu \mathrm{m}$, 浸漬 1000 時間後で約 $2.1 \mu \mathrm{m}$ で あった。

Fig. 7 には $\mathrm{Si}_{3} \mathrm{~N}_{4}$ の浸漬 1000 時間後の破面打よび EPMA 分析結果を示す。表層部では, 焼結助剤 Ce が溶 出し硫酸成分 S が浸透している多孔質な層が形成された 


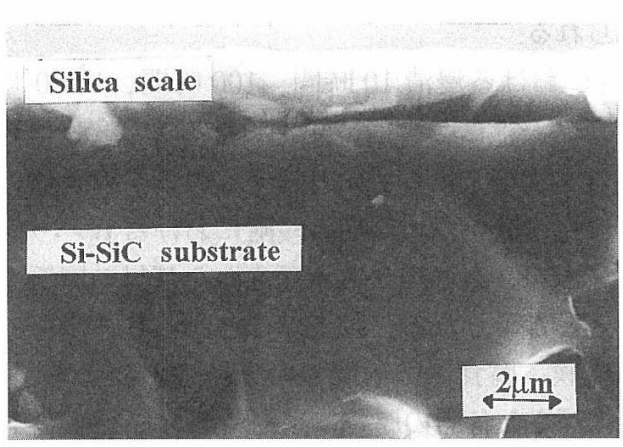

Fig. 5. Fracture surface of $\mathrm{Si}-\mathrm{SiC}$ after $1000 \mathrm{hr}$ immersion in boiling $95 \%$ sulfuric acid.
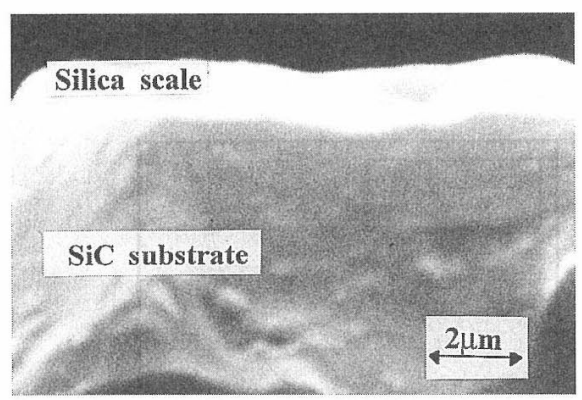

Fig. 6. Fracture surface of $\mathrm{SiC}$ after $1000 \mathrm{hr}$ immersion in boiling $95 \%$ sulfuric acid.

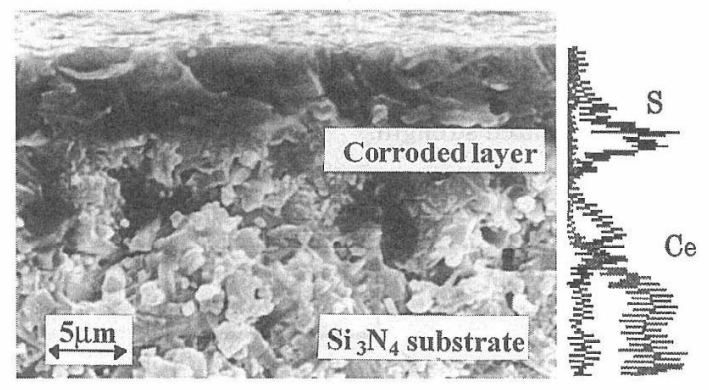

Fig. 7. Fracture surface of $\mathrm{Si}_{3} \mathrm{~N}_{4}$ after $1000 \mathrm{hr}$ immersion in boiling $95 \%$ sulfuric acid.

ことが確認できる(以後腐食層と記述)。その表面には比 較的平滑な破面様相を示す層（以後皮膜と記述）がほぼ 全面に確認でき，その主成分は Si と O であったことか らシリカ皮膜が生成されたと考えられる。皮膜は浸漬 100 時間後の表面においても確認され, その厚さは浸漬 100 時間後で約 $2.0 \mu \mathrm{m}$, 浸漬 1000 時間後で約 $6.0 \mu \mathrm{m}$ で あった。また, 腐食層の厚さは, 浸漬 100 時間後に約 $10 \mu \mathrm{m}$ ，浸漬 1000 時間後に約 $20 \mu \mathrm{m}$ と増加した。

$\mathrm{Al}_{2} \mathrm{O}_{3}$ の浸漬 100 時間後の破面を Fig. 8 に示す。表面 には粒界が不明瞭しなった多孔質な層が確認できる。 EPMA 分析から, 主成分 $\mathrm{Al}$ 扎よび $\mathrm{O}$ が溶出し, 硫酸成 分 Sが浸透した腐食層が存在することが明らかとなった。 この腐食層の厚さは浸漬 100 時間後で約 $17 \mu \mathrm{m}$, 浸漬 1000 時間後で約 $50 \mu \mathrm{m}$ と浸漬時間と共に増加した。

Fig. 9 に $\mathrm{ZrO}_{2}$ の破面を示す。表面に明瞭な腐食孔が 確認でき, 腐食孔底部からき裂が進展した破面様相を呈 している。Sが浸透した腐食層の生成が浸漬 0.1 時間後

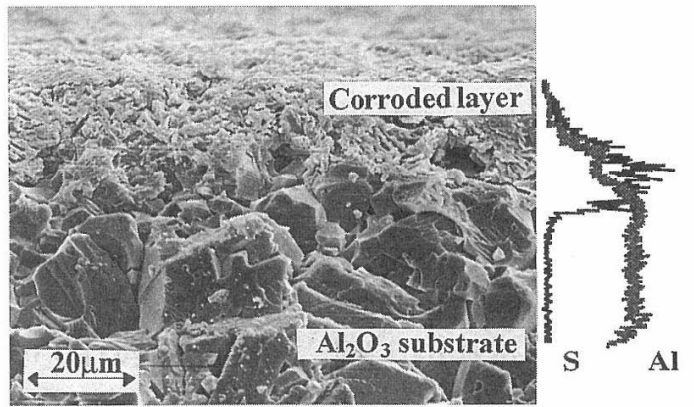

Fig. 8. Fracture surface of $\mathrm{Al}_{2} \mathrm{O}_{3}$ after $100 \mathrm{hr}$ immersion in boiling $95 \%$ sulfuric acid.

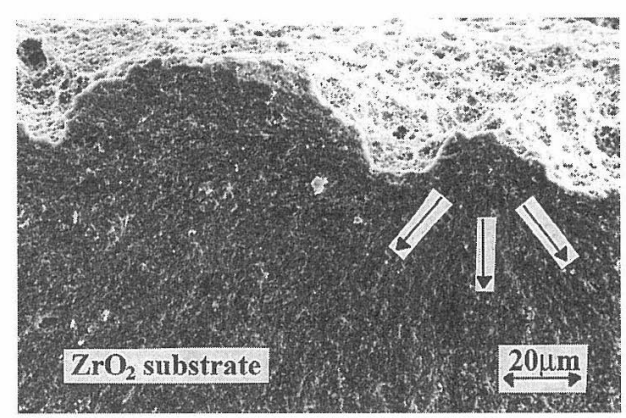

Fig. 9. Fracture surface of $\mathrm{ZrO}_{2}$ after $10 \mathrm{hr}$ immersion in boiling $95 \%$ sulfuric acid.

ですでに観測され，先の厚さは約 $20 \mu \mathrm{m}$ であった。先の 後の浸漬時間による表面からの腐食層厚さの増加は認め られなかった。

\section{4 考察}

\section{$4 \cdot 1 \quad \mathrm{D}-\mathrm{L} / \mathrm{D}$ 曲線による腐食層の評価}

本実験で用いた各種セラミックスの腐食後の強度と腐 食減量扣よび硬度との相関を Fig. 10 および Fig. 11 にま とめて示す。な拊, 強度と硬度については最大値と最小 值も示した. Fig. 10 に示すように, $\mathrm{ZrO}_{2}$ の強度は質量 減少と共に低下する傾向を示したが，他の 4 種類のセラ ミックスについては強度と質量との明膫な相関が認めら れない。したがって， $\mathrm{ZrO}_{2}$ の場合では腐食による強度劣 化すなわち耐食性を質量変化から評価することが可能で あるが，他の 4 種類については困難であると考光られる。 そこで，見かけの硬度と曲け強度との相関を見てみると， $\mathrm{Si}-\mathrm{SiC}, \mathrm{SiC}$ に打いては硬度の低下に従って強化する傾向 (右下がり)， $\mathrm{Si}_{3} \mathrm{~N}_{4}, \mathrm{Al}_{2} \mathrm{O}_{3}$ に扰いては劣化する傾向（右 上がり）を示すことが分かる。すなわち，腐食表面状態 を反映する見かけ硬度を用いて, 表面状態に影響される セラミックス材の強度変化を評価することが可能である と推測される。

爷こで，硬度変化を連続的に評価できる D-L/D 曲線 の傾き，すなわち $\mathrm{B}$ パラメータの変化と腐食層断面の様

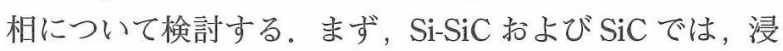
漬 100 時間, 1000 時間後の B パラメータは 2 段階に変化 した。この変化は，表面に生成したシリカ皮膜 / $\mathrm{Si}-\mathrm{SiC}$ 基 材の界面の存在によると考光られる。すなわち, 皮膜を形 成する非晶質シリカの硬度は基材の約半分と小さい ${ }^{16)}$ た 
め，押込み深さが小さいときには B パラメータには皮膜 の硬さが支配的となり基材に比べ低下する，さらに，あ る押込み深さ以上では基材からの影響が次第に大きくな り，Bパラメータは増加すると考えられる，その後，B パラメータは基材の硬さに漸近するが皮膜の効果により 基材自身の值より低下する。 また, 皮膜の効果は, 皮膜 厚さ, すなわち浸漬時間の増加に伴って増大する。

$\mathrm{Si}_{3} \mathrm{~N}_{4}$ における浸漬 100 時間， 1000 時間後の B パラメ 一タは 3 段階に変化した。これは，表面に形成された皮 膜とその下部に助剤の溶出により生成される多孔質層と の二層から成る腐食層に起因する.すなおち, 基材を含 む各層の硬さは基材 > 皮膜 > 多孔質層の順であり，この ような 3 層構造により $\mathrm{B}$ パラメータが 3 段階に変化した
と考えられる.

$\mathrm{Al}_{2} \mathrm{O}_{3}$ における浸漬 10 時間, 100 時間, 1000 時間後 の Bパラメータは 2 段階に変化した。 この変化は表面に 生成した腐食層によるものと考えられる，腐食層の硬度 は基材に比べ低いため初期の段階における B パラメータ は低下するが，ある押し込み深さから基材の影響を受け 増加すると考えられる．以上のことから B パラメータの 変化は皮膜, 腐食層の層間の力学特性の変化を反映し, その変化深さと各層の厚さには相関があると考えられる。

そこで，Bパラメータが変化した深さ (d) と破面観察 および EPMAにより特定した $\mathrm{SiC}, \mathrm{Si}-\mathrm{SiC} に$ 対する皮膜 あるいは $\mathrm{Al}_{2} \mathrm{O}_{3}, \mathrm{Si}_{3} \mathrm{~N}_{4}$ で確認できた腐食層の厚さ $(\mathrm{T})$ と の関係を Fig. 12 に示す. なお，最大值と最小值をそれ
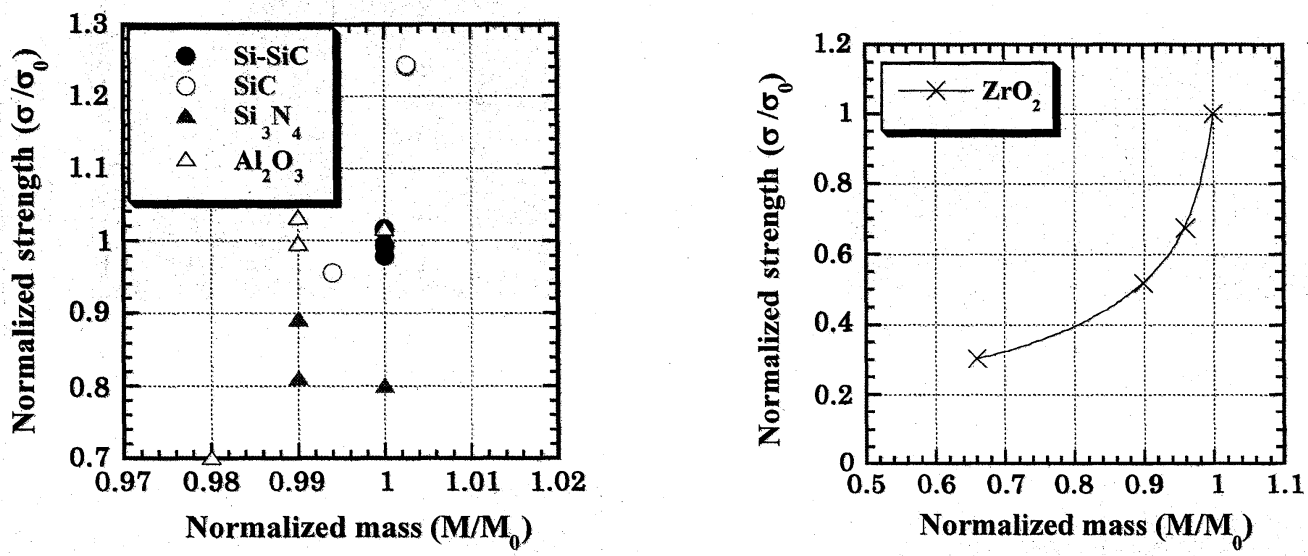

Fig. 10. Relationship between normalized mass and normalized strength.
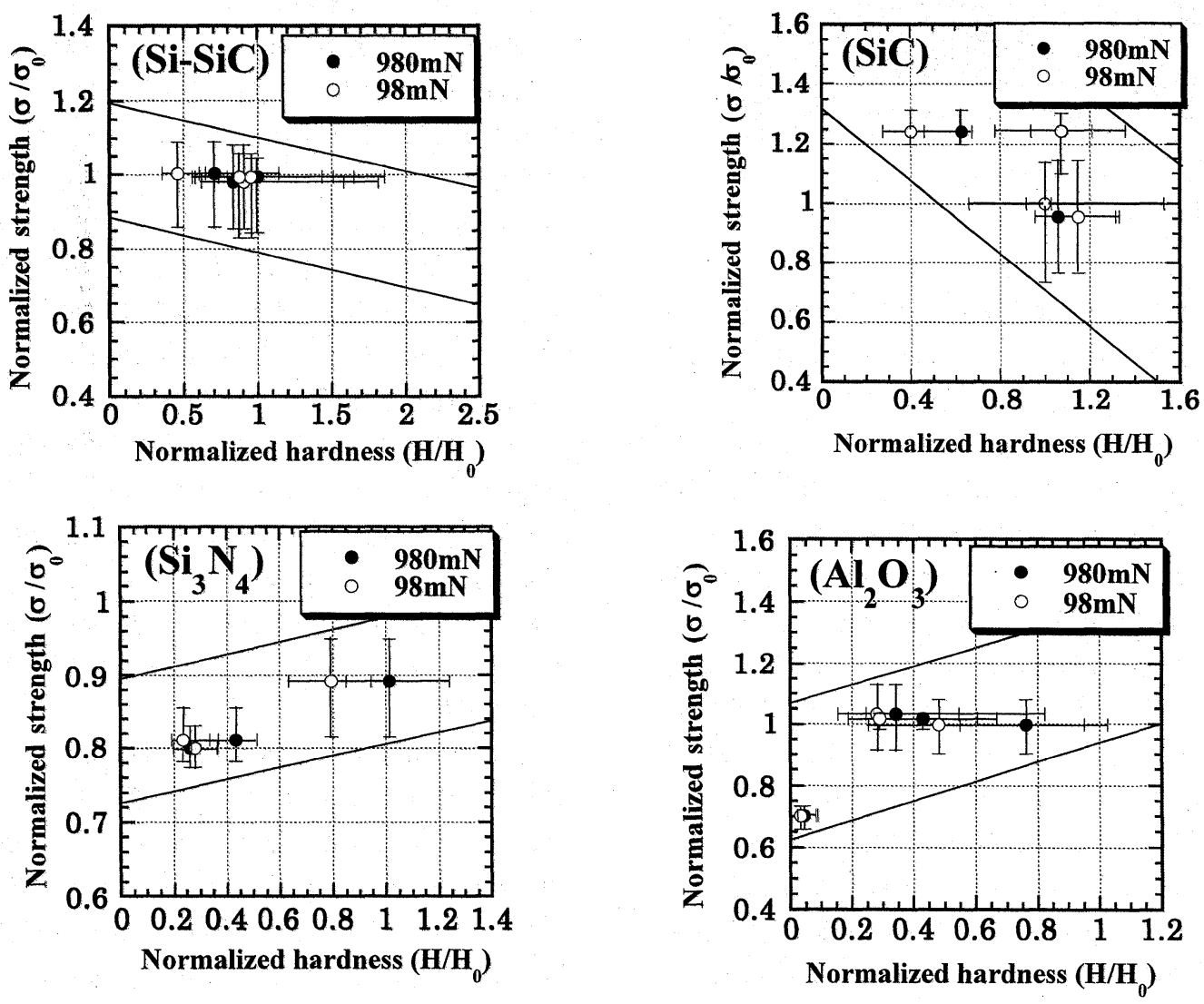

Fig. 11. Relationship between normalized hardness and normalized strength. 
ぞれバーで示す．困中に示すように両者は

$$
T \approx 10 d
$$

の関係式でほぼ整理できることが分かる.ただし， 0.2 $\mu \mathrm{m}$ 以下の皮膜では厚さ $\mathrm{T}$ と $\mathrm{d}$ 值の関係は式 (1) を十分 満足しなくなる傾向が見られる。これは圧子先端鈍化の 影響 ${ }^{17)}$ が皮膜厚さが小さいときに増大したことによると 考えられる，さらに，この関係について FEMによる多 層薄膜構造に関する接触解析を実施しており，実験結果 の妥当性をほぼ確認している. ${ }^{18)}$

$\mathrm{Si}-\mathrm{SiC}, \mathrm{SiC}$ に生成したシリカ皮膜は硫酸に対して優れ た耐食性を有するため，両材の強度劣化が生じなっかた

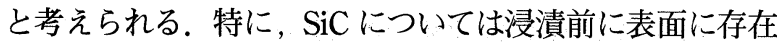
していた気孔などの欠陥が酸化皮膜の生成によって閉塞 または鈍化したため, 浸漬 100 時間後の強度が幾分増加 したと考元られる.19) このような皮膜の厚さを微小押し込 み試験法により求まる押込み荷重一深さ曲線と式 (1)の 関係を用いることで非破壊的に評価できることが分かる.

\section{$4 \cdot 2$ D-L/D 曲線による強度劣化の評価}

$\mathrm{Si}_{3} \mathrm{~N}_{4}, \mathrm{Al}_{2} \mathrm{O}_{3}$ の強度劣化は, 多孔質な腐食表層の形成 よると考えられる. Smialek $~^{{ }^{10)}}$ は，炭化ケイ素の高温 溶融塩環境下での強度劣化特性が表面に形成されたピッ トの深さの $1 / 2$ 乗に比例するとしている. 荒井ら ${ }^{14)}$ は窒 化ケイ素の水酸化ナトリウム水溶液中腐食後劣化特性を 腐食層を表面縁き裂と仮定すれば母材の破壊強度特性と 良く一致することを見出した，また，岡田ら ${ }^{12)}$ は，荎化 ケイ素の硫酸溶液中では，腐食層寸法に相当した直径を 有するぺニーシェイプ状のき裂が破壊強度を支配すると 報告している。皃こで， $\mathrm{Si}_{3} \mathrm{~N}_{4}, \mathrm{Al}_{2} \mathrm{O}_{3}$ について，広範囲 に形成された多孔質状の腐食層が強度劣化を誘発する表 面欠陥であり，腐食層厚さを表面縁き裂であると考元， Table II に示した浸漬前の破壞じん性值 $K_{I C}$ を用いて曲 げ強度 $\sigma$ を整理すると Fig. 13 の直線のようになる。こ こで, 図中の横軸で示した等価縁き裂寸法 $a_{e}$ は次式 ${ }^{20}$ から求めた。

$$
a_{e}=\left(K_{I C} / 1.12 \sigma\right)^{2} / \pi
$$

また, $d$ 值を用いて式 (1) の関係より評価した腐食層厚 さと腐食後強度評価の結果を合わせて示す $\left(\mathrm{Si}_{3} \mathrm{~N}_{4}\right.$ の $d$ 值は，腐食層厚さを表す 2 段目の折れ曲がり点から評価 された值を用いた)． $\mathrm{Si}_{3} \mathrm{~N}_{4}$ の 1000 時間腐食後の結果を 除き, 両材料の腐食後強度はほぼ式 (2) の関係で表せる ことが分かる.すなわち，等価なき裂寸法 $\left(a_{e}\right)$ と腐食層 の厚さ $(T)$, さらに層間の力学特性変化に起因した押込 み深さ $(d)$ との間には,

$$
a_{e} \approx T \approx 10 d
$$

の関係が成り立ち，押込み試験より評価できる $d$ 值から 腐食後の強度劣化を非破壊的に評価することが可能とな

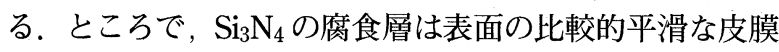
とその下部の多孔質層の二層から成り，1000 時間では皮 膜厚さは腐食層厚さの約 $1 / 3$ に達する。このような平滑 な皮膜には強化効果がある ${ }^{19)}$ ことから，腐食層厚さと同 程度の式 (2) で評価される等価き裂寸法に対する強度に 比べて 1000 時間腐食後強度は増加したと考えられる.

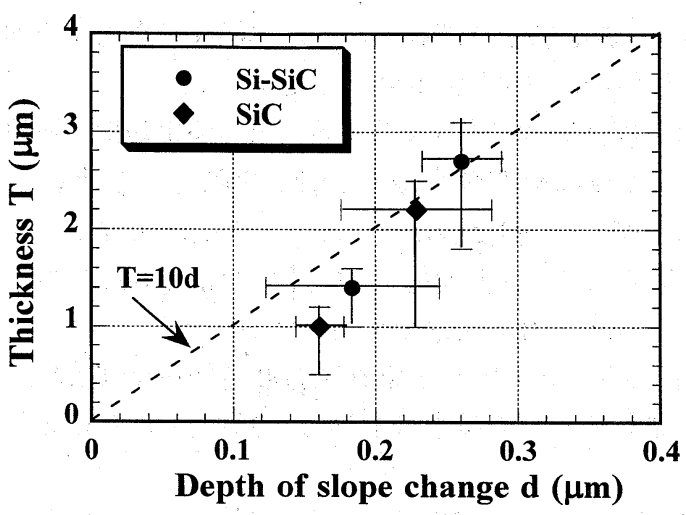

(a) Thickness of scale

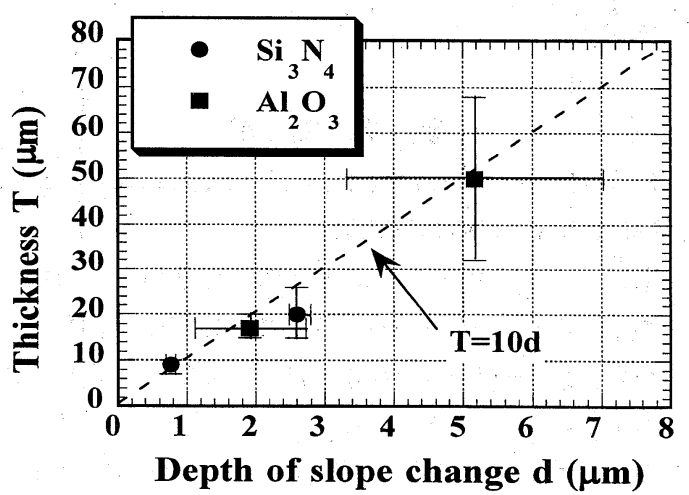

(b) Thickness of corroded layer

Fig. 12. Relationship between depth of slope change obtained from D-L/D curve and thickness of layer.

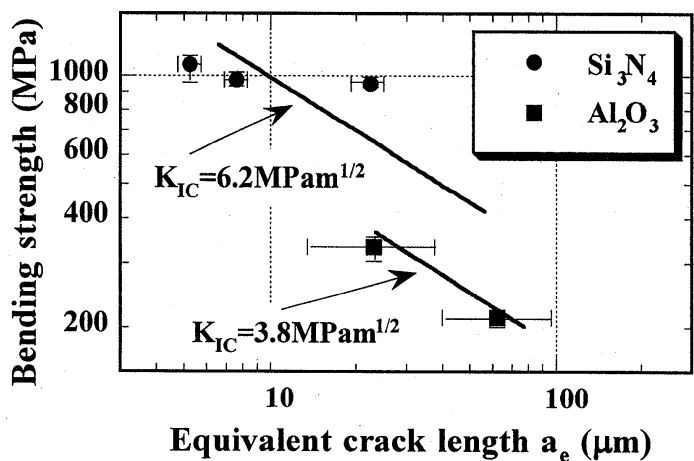

Fig. 13. Bending strength of $\mathrm{Si}_{3} \mathrm{~N}_{4}$ and $\mathrm{Al}_{2} \mathrm{O}_{3}$ as a function of equivalent crack length calculated from depth of slope change.

\section{5 結 言}

沸騰濃硫酸環境において，5種類のセラミックスに対 する浸漬試験，および腐食後強度評価，さらに腐食面表 層の力学特性の変化を微小押込み試験を行い検討した結 果, 以下の結論を得た。

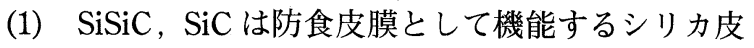
膜の生成によ優れた耐食性を示す。一方, $\mathrm{Si}_{3} \mathrm{~N}_{4}, \mathrm{Al}_{2} \mathrm{O}_{3}$, $\mathrm{ZrO}_{2}$ は多孔質な腐食層の形成により強度劣化を示した。

（2）腐食面表層の腐食形態の差異を，特に力学特性 の変化という観点から, 微小押し込及試験により評価す ることが可能である.

（3）表面に生成した皮膜あるいは腐食層厚さ $(T)$ は， 
微小押込み試験から評価される力学特性が変化する押込 み深さ $(d)$ を用いて $T \approx 10 d$ として表せる.

(4) 腐食層内に生成する皮膜による強化効果が無視し 得ない 1000 時間腐食後の $\mathrm{Si}_{3} \mathrm{~N}_{4}$ を除き, 腐食による $\mathrm{Si}_{3} \mathrm{~N}_{4}, \mathrm{Al}_{2} \mathrm{O}_{3}$ の強度劣化を, 浸漬前の破壊勒性值と腐食 層の厚さ $(T)$ を表面縁き裂と仮定した等価き裂寸法 $\left(a_{e} \approx T \approx 10 d\right)$ を用いて評価することができる.

(5) (2)，(3)，(4) から腐食後強度劣化を非破壊的に評 価する手法として微小押し込み試験は有効であるとい える.

終わりに, SEM, EPMA 分析にご協力いただいた深谷 清氏, 硫酸元素分析にご協力いただいた樋田行雄氏に感 謝します.

\section{参 考 文 献}

1) K. Onuki, H. Nakajima, I. Ioka, M. Futakawa and S. Shimizu, JAERI-Review 94-006 (1994).

2 ）小貫 薰, 中島隼人, 清水三郎, 佐藤章一, 田山一郎, 水素エネルギーシステム, 18, 49 (1993).

3 ) 小貫 薰, 中島隼人, 清水三郎, 佐藤章一, 田山一郎, 水 素エネルギーシステム, 19, 10 (1994).

4 ）小貫薰, 井岡郁夫, 二川正敏, 中島隼人, 清水三郎, 田山一郎, 材料と環境, 46, 113 (1997).

5) 川久保 隆, 平山秀雄, 後藤 昭, 金子 正, 材料, 38 , 300 (1988).

6) 田中大輔, 相馬才晃, 杉本克久, 材料と環境, 42, 585
(1993).

7）吉尾哲夫, 小田耕平, 材料と環境，40，96（1991）.

8）川久保 隆, 平山秀雄, 金子 正, 材料, 39, 312 (1989).

9) 浅野鐵夫, 岡田 明, 飯尾 聡, 吉村昌弘, Journal of the Ceramics Society of Japan, 101, 589 (1993).

10) J. L. Smialek and N. S. Jacobson, J. Am. Ceram. Soc., 69, 741 (1986).

11) 岡田 明, 飯尾 聡, 浅野鐵夫, 小梶 彰, 高橋秀雄, 吉村昌弘, 日本セラミックス協会学術論文誌, 99, 1260 (1991).

12) 岡田 明, 飯尾 聡, 浅野鐵夫, 吉村昌弘, 日本セラミック 不協会学術論文誌，100，80（1991）。

13) 岡田 明, 飯尾 聡, 浅野鐵夫, 吉村昌弘, 日本セラミ ックス協会学術論文誌, 100,965（1991）。

14）荒井雅嗣, 河野顕臣, 材料と環境, 44，276（1995）.

15）稲村元則, 鈴木敬愛; 生産研究, 42, 4, 257 (1990).

16）日本セラミックス協会編, “セラミックス工学ハンドブッ ク”（1989）技報堂出版.

17）松岡三郎, 宮原健介, 長島伸夫, 田中紘一, 日本機械学 会論文集, A-62, 1432 (1996).

18) Y. Stockmann and M. Futakawa, 日本機械学会茨城講演会 論文集, p.115 (1997).

19）二川正敏，小貫：薰， R. W. Steinbrech，表面技術，48， 662 (1997).

20）中沢 一, 小林英男, “固体の強度”, p.99（1976）共立出版. 